\title{
Ação Declaratória de Constitucionalidade: expectativa, realidade e algumas propostas ${ }^{1}$
}

\author{
Declaratory Action of Constitutionality: expectation, \\ reality and some proposes
}

\section{Fábio Carvalho Leite}

Pontifícia Universidade Católica do Rio de Janeiro (PUC-Rio) - Rio de Janeiro, RJ, Brasil

\begin{abstract}
Resumo: Neste trabalho, sustenta-se que a ação declaratória de constitucionalidade apresenta alguns pontos ainda indefinidos e que a sua legitimidade depende da interpretação desses aspectos. Esses pontos são identificados a partir do confronto da abordagem doutrinaria a respeito desta ação com a sua aplicação pelo Supremo Tribunal Federal. Ao final, é realizada uma análise crítica e propositiva a respeito desses pontos indefinidos.
\end{abstract}

Palavras-chave: Ação Declaratória de Constitucionalidade. Controle de Constitucionalidade. Supremo Tribunal Federal. Jurisdição Constitucional.

\begin{abstract}
This paper claims that the declaratory action of constitutionality reveals some undefined points and that its legitimacy depends on the interpretation of theses aspects. These points are identified through the confrontation of doctrinal approach about this action with its application by the Supreme Court. The paper concludes with a critical analysis of these undefined points and some proposals that should be taken into account when trying to untangle them.
\end{abstract}

Keywords: Declaratory Action of Constitutionality. Judicial Review. Supreme Federal Court. Constitutional Jurisdiction.

\section{Introdução}

A Ação Declaratória de Constitucionalidade (ADC) se reveste de uma complexidade que tem sido negligenciada ou ocultada pela doutrina e pelo STF que, grosso modo, praticamente a reduzem a uma mera "Ação Direta de Inconstitucionalidade (ADI) com sinal trocado". Essa equipa-

1 Recebido em: 23/5.2014

Revisado em: 17/9/2014

Aprovado em: 22/9/2014 
ração é possível, mas em termos bem mais limitados do que se supõe. Há nuances que distinguem a ADC, algumas sutis, mas todas relevantes e que vão muito além dos aspectos mais visíveis relativos à conformidade ou inconformidade de uma lei com o texto constitucional do qual extrai seu fundamento de validade.

Neste estudo, defende-se que a legitimidade da ADC depende justamente desses pontos nebulosos, que, a depender de como forem compreendidos, podem tornar a ação um instrumento necessário à segurança jurídica, respeitando as saudáveis e esperadas divergências que resultam da abertura no processo de interpretação constitucional (HABERLE, 2007) ou uma ação que centraliza a jurisdição constitucional num único tribunal, confiando o sentido do texto constitucional às leituras (por vezes individuais e/ou isoladas) de seus onze integrantes - ou algo entre estes dois extremos.

O trabalho divide-se em três partes: na primeira ("o que a ADC é") reúne-se os pontos básicos dessa ação segundo as considerações teóricas feitas pela doutrina; na segunda ("o que a ADC tem sido"), apresenta-se e analisa-se brevemente a forma como a ADC tem sido interpretada pelo STF em sua jurisprudência; e na terceira parte ("o que a ADC deveria ser") faço uma abordagem de caráter crítico-propositivo diante de alguns problemas relativos a essa ação, ou ao modo como tem sido interpretada, e que poderiam comprometer a sua legitimidade.

\section{O que a ADC é}

A Ação Declaratória de Constitucionalidade (ADC) foi introduzida na Constituição de 1988 pela emenda constitucional n. 3, de 1993, e representou uma verdadeira "inovação" no ordenamento jurídico brasileiro (BARROSO, 2004, p. 176; LEITE 2008, p. 86-87), a despeito dos que alegam que tal ação já poderia ser identificada na representação de inconstitucionalidade, em função da possibilidade de ajuizamento daquela ação pelo Procurador-Geral da República com parecer contrário, ou seja, 
contra a inconstitucionalidade da lei (MENDES, 2012, p. 42) - embora na prática jamais tenha sido compreendida dessa forma ${ }^{2}$.

Trata-se de uma ação de controle abstrato-concentrado (ou seja, que implica a análise da constitucionalidade da lei em tese, desvinculada de qualquer caso concreto, a ser julgada por um único órgão, no caso o STF), tendo por objeto ato normativo federal, cuja constitucionalidade esteja sendo alvo de controvérsia judicial. A ação pode ser proposta pelos mesmos órgãos e agentes legitimados para ajuizar a $\mathrm{ADI}^{3}$, sempre com o objetivo de que seja confirmada a constitucionalidade da lei federal em questão, tendo a decisão efeito vinculante aos órgãos do Poder Judiciário (juízes e tribunais) e à administração pública (direta e indireta) dos três Poderes nos três níveis da federação, não podendo mais a lei deixar de ser aplicada por qualquer destes sob a alegação de sua inconstitucionalidade.

$\mathrm{O}$ advento da ADC ensejou um amplo debate a respeito da sua própria constitucionalidade (MARTINS; MENDES, 2001, p. 247-248), o que reforça ainda mais o caráter inovador da ação. Até então, o controle de constitucionalidade brasileiro, embora classificado como misto ou híbrido, era fortemente marcado pela via difusa, já que os juízes e tribunais gozavam de independência absoluta para declarar a inconstitucionalidade de uma norma e só não poderiam mais fazê-lo quando o STF julgasse procedente uma ADI - e isso menos por um respeito ao entendimento do STF como uma espécie de Corte Constitucional e mais pela própria

2 O Ministro Sepúlveda Pertence, quando no exercício do cargo de Procurador-Geral da República, chegou a ajuizar representação de inconstitucionalidade (RI n. 1349, por exemplo) com pedido explícito pela declaração de constitucionalidade, mas o STF, nas palavras do próprio Ministro, "entendeu que eu me excedera na franqueza e julgou inepta a petição inicial" - entendimento que foi reiterado pelo Ministro Moreira Alves, ao frisar que a ação declaratória de constitucionalidade "não é, data venia do Ministro Sepúlveda Pertence, uma ação direta de inconstitucionalidade às avessas, como V.Exa. pretendeu usá-la quando era Procurador-Geral da República". (citações extraídas de manifestação do Min. Sepúlveda Pertence no julgamento do Ag. Reg. na Reclamação n. 1.880-6/SP 07/11/2002).

3 Inicialmente a ADC podia ser proposta apenas pelo Presidente da República, pelas as Mesas diretoras da Câmara dos Deputados e do Senado Federal e pelo ProcuradorGeral da República (EC 3/93 e art. 13 da lei 9868/99). A Emenda Constitucional 45/2004 ampliou o rol de legitimados. 
consequência daquela decisão, a saber: o afastamento da norma inconstitucional do ordenamento jurídico. Em síntese, não apenas os juízes e tribunais do País poderiam, pela via do controle concreto-difuso, manifestar entendimentos divergentes entre si acerca da constitucionalidade de uma mesma norma, como poderiam fazê-lo ainda que o STF já tivesse manifestado entendimento pela sua constitucionalidade, seja incidentalmente, no julgamento de um caso concreto, seja na decisão pela improcedência de uma ADI. A ADC, então, foi criada com o intuito de afastar a incerteza acerca da validade de uma lei ou ato normativo federal que poderia resultar deste estado de coisas.

A inconstitucionalidade da ação declaratória de constitucionalidade, no entanto, era uma tese de difícil sustentação e não por acaso este ponto foi superado quase à unanimidade pelo STF (vencido apenas o Ministro Marco Aurélio) ao julgar questão de ordem na ADC n. 1. Os argumentos pela inconstitucionalidade envolviam basicamente a violação da independência do Judiciário, mais especificamente a livre convicção do magistrado (artigo 60, $\S 4^{\circ}, \mathrm{III}, \mathrm{CRFB}$ ), e a inobservância do contraditório (artigos $5^{\circ}, \mathrm{LV}$, e $\left.60, \S 4^{\circ}, \mathrm{IV}, \mathrm{CRFB}\right)$. De fato, a ADC implicava uma mudança profunda no controle de constitucionalidade brasileiro e, portanto, dava nova configuração à separação de poderes, ou à independência do Judiciário e de seus membros. Daí não se pode afirmar, contudo, que violava a essência do princípio em questão. Ademais, a Constituição protege este valor contra emendas "tendentes a aboli-lo" (artigo 60, $\left.4^{\circ}, \mathrm{III}, \mathrm{CRFB}\right), \mathrm{o}$ que definitivamente não era o caso.

O argumento de inobservância do contraditório suscitou maior ponderação. Dos nove ministros que se manifestaram pela constitucionalidade da ADC, três (Sepúlveda Pertence, Ilmar Galvão e Carlos Velloso) adotaram o entendimento de que o STF deveria dar publicidade do ajuizamento da ação a fim de que os legitimados à propositura da ADI pudessem se manifestar pela inconstitucionalidade, se assim entendessem, assegurando, desse modo, um mínimo de contraditório. Prevaleceu, contudo, o entendimento do Relator, Ministro Moreira Alves, de que, por se tratar de um processo objetivo, não estaria sujeito ao contraditório. 
Outra crítica lançada contra a ADC (além da suposta violação a tais cláusulas pétreas) foi a de que esta ação implicaria o fim do controle concreto-difuso de constitucionalidade. A crítica não parece correta - e talvez seja excessivamente dramática. A ADC jamais poderia acabar com o controle concreto-difuso justamente porque este é um pressuposto para o ajuizamento da ação, que, a rigor, não tem o propósito de declarar, mas confirmar a constitucionalidade de uma lei federal que seja alvo de controvérsia judicial (controle concreto-difuso). Mais do que um aspecto importante, trata-se de um traço característico e fundamental para se compreender a ADC. O exercício prévio do controle concreto-difuso e a eventual divergência judicial daí resultante serão a matéria-prima a partir da qual o STF poderá exercer o controle abstratoconcentrado através da ADC, que não busca afastar a insegurança decorrente da possibilidade do exercício do controle difuso, mas a insegurança que resulta deste. Concilia-se assim a certeza jurídica (controle concentrado), afinal necessária, com a democratização da interpretação constitucional (controle difuso).

Esse aspecto da ação declaratória de constitucionalidade foi ressaltado já no julgamento da ADC 1, onde o relator, min. Moreira Alves, observou:

Partindo do pressuposto de que é ínsita à propositura dessa ação a demonstração, em sua inicial - com a juntada de sua comprovação -, da controvérsia judicial que põe risco a presunção de constitucionalidade do ato normativo sob exame, observo que, no caso, esse requisito está devidamente preenchido, permitindo à Corte o conhecimento das alegações em favor da constitucionalidade e contra ela, e do modo como estão sendo decididas num ou noutro sentido.

Este pressuposto para o ajuizamento da ação afirmado pela via jurisprudencial ${ }^{4}$ foi acolhido pela Lei n. 9.868/99 (que regulamentou o processo e julgamento da ADI e ADC, e recentemente também da ADIO), ao

4 Outros ministros destacaram este mesmo aspecto no julgamento da questão de ordem na ADC n.1. 
dispor expressamente que a petição inicial da ação deverá indicar "[...] a existência de controvérsia judicial relevante sobre a aplicação da disposição objeto da ação declaratória" (art. 14, III). Nota-se que a legislação foi precisa ao adotar a expressão controvérsia judicial relevante, que convém ser analisada detidamente. Ao afirmar tratar-se de controvérsia judicial, a lei afastou divergências doutrinárias como permissivas do ajuizamento da ação e, ao qualificar tal controvérsia como relevante, permitiu ao STF certa discricionariedade em relação ao objeto da ADC, decorrente de um juízo prévio acerca da sua relevância. Tais observações, todavia, definem apenas o que não atende a este pressuposto, mas não esclarecem o que seria esta controvérsia judicial que permite o ajuizamento da ação. Não há dúvida de que a coexistência de decisões judiciais pela inconstitucionalidade e pela constitucionalidade de uma mesma norma é capaz de gerar uma controvérsia que, nos termos do voto citado, permitiria à Corte "[...] o conhecimento das alegações em favor da constitucionalidade e contra ela". No entanto, resta saber se, para se caracterizar a controvérsia judicial, deve necessariamente haver decisões tanto pela inconstitucionalidade como pela constitucionalidade da norma - o que permitiria ao STF conhecer os argumentos judiciais contrários e favoráveis à constitucionalidade do ato normativo ou se bastaria a existência de decisões judiciais (todas) pela inconstitucionalidade de uma norma para a caracterização daquela controvérsia de que trata a lei.

Adotado este segundo entendimento, caso diversos juízes e tribunais do País deixassem de aplicar uma medida provisória por entendê-la inconstitucional, o Presidente da República, único autor daquele ato normativo, poderia ajuizar uma ADC e, se o STF, por maioria, julgasse procedente a ação, os juízes e tribunais estariam obrigados a aplicar aquele ato normativo, ainda que não tivesse ocorrido até então absolutamente nenhuma decisão judicial neste sentido.

Por outro lado, adotado com rigor o primeiro entendimento, talvez não tivesse sido possível, por exemplo, o ajuizamento de uma ADC tendo por objeto a Resolução n. 7/2005 do CNJ - ato normativo que vedou a prática do nepotismo em todos os órgãos do Poder Judiciário - caso todos 
os Tribunais do País tivessem deixado de observar a norma alegando a sua inconstitucionalidade. ${ }^{5}$

Em linhas gerais, a ADC guarda muitas semelhanças com a ADI, ainda que os propósitos sejam visivelmente opostos. Afinal, em ambas as ações, ajuizadas pelos mesmos órgãos e agentes, um mesmo tribunal (no caso, o STF) manifesta-se sobre uma mesma questão: a constitucionalidade de lei ou ato normativo. Assim, embora as ações tenham propósitos distintos, o julgamento de qualquer das duas acabará por trazer a resposta a uma pergunta comum a ambas: afinal, a norma em questão é ou não constitucional? Por um raciocínio lógico, uma norma não pode, em sede de fiscalização abstrata, ser constitucional e inconstitucional simultaneamente, assim como não poderá não ser constitucional sem deixar de ser inconstitucional ${ }^{6}$. Desse modo, a procedência de uma deveria equivaler à improcedência da outra, e vice-versa. Em linhas gerais, esta é a tese da ambivalência das ações de constitucionalidade e inconstitucionalidade, que afirma que essas são "ações iguais com sinal trocado".

A tese da ambivalência foi, de certo modo, positivada na Lei n. 9.868/99, resultando da leitura conjugada dos artigos 24 e 28, parágrafo único:

Art. 24 Proclamada a constitucionalidade, julgar-se-á improcedente a ação direta ou procedente eventual ação declaratória; e, proclamada a inconstitucionalidade, julgar-se-á procedente a ação direta ou improcedente eventual ação declaratória.

5 Esta questão não precisou ser enfrentada porque houve, de fato, manifestações tanto pela constitucionalidade como pela inconstitucionalidade da norma, configurando assim a controvérsia judicial que permitiu o ajuizamento da ADC n. 12. Nos termos da petição inicial da ADC 12, “[...] alguns Tribunais têm aplicado a Resolução com rigor, ao passo que outros já declararam que não pretendem aplicá-la. Mandados de segurança têm sido impetrados pelo país afora contra a aplicação da Resolução e, de acordo com a informação que foi possível obter, há liminares afastando sua aplicação no Rio de Janeiro, Minas Gerais e Mato Grosso do Sul".

6 Deixa-se aqui de lado, por ser inaplicável ao caso, a distinção entre inconstitucionalidade "as enacted" e inconstitucionalidade "as applied" - tema que, no entanto, considero fundamental para as reflexões sobre os rumos do controle de constitucionalidade no Brasil. 
$[\ldots]$

Art. 28 - parágrafo único - A declaração de constitucionalidade ou de inconstitucionalidade [...] têm eficácia contra todos e efeito vinculante em relação aos órgãos do Poder Judiciário e à Administração Pública federal, estadual e municipal. BRASIL, 1999, art. 24-28)

Nota-se que a redação do artigo 24 confere maior destaque ao resultado alcançado no julgamento (constitucionalidade ou inconstitucionalidade), deixando em segundo plano a identificação da ação que fora ajuizada (ADI ou ADC). É dizer, importa saber se a lei objeto da ação foi considerada constitucional ou inconstitucional para só então, a partir daí, decidir o destino da ação. Levado o texto legal ao extremo, significaria afirmar que a Corte não julga procedente ou improcedente uma ação, para declarar a lei constitucional ou inconstitucional; antes, ela reconhece que uma lei é constitucional ou inconstitucional para aí então julgar a ação procedente ou improcedente, numa curiosa inversão de ordem. De todo modo, proclamada a constitucionalidade ou a inconstitucionalidade do ato normativo objeto da ação, seja pela procedência ou improcedência da $\mathrm{ADI}$ ou da ADC, esta declaração terá eficácia contra todos e efeito vinculante, conforme dispõe o artigo 28, supra.

Outro ponto a ser destacado em relação à $\mathrm{ADC}$ refere-se à medida de cautelar, hipótese que, aliás, não tem previsão constitucional expressa. A despeito deste "silêncio" da Constituição, que atribui competência ao STF para julgar o pedido de medida cautelar apenas das ações diretas de inconstitucionalidade (artigo 102, I, p), o tribunal, no julgamento da ADC -MC 4, entendeu, por maioria (vencidos os ministros Ilmar Galvão e Marco Aurélio), que “[...] pode a Corte conceder medida cautelar que assegure, temporariamente, tal força e eficácia à decisão de mérito [...] mesmo sem expressa previsão constitucional de medida cautelar em ADC, pois o poder de acautelar é imanente ao de julgar" (ADC-MC 4). Superada essa questão, restava então determinar o efeito e a extensão da medida cautelar. Esse ponto gerou intenso e justificado debate. Afinal, em que consistiria uma cautelar em ADC? Seria uma espécie de julgamento antecipado como ocorre com a cautelar em ADI? Nesse caso, estariam juízes e tribunais obrigados a aplicar a lei federal até o julgamento definitivo 
pelo STF? Ou deveria implicar a suspensão dos processos em que a constitucionalidade da lei fosse questão prejudicial? Nesse caso, por quanto tempo ficariam suspensos os processos? Esta, aliás, foi uma preocupação demonstrada pelo Ministro Nelson Jobim, que sugeriu:

[...] seria oportuno que fixássemos um prazo para decidirmos o mérito (...) Não podemos ficar com esse assunto pendente por dois, três anos. Ele tem que ser definido. O mérito, neste caso, levou dez anos para ser julgado (01/10/2008).

\section{O Que a ADC Tem Sido}

Até o momento, foram ajuizadas 32 ADCs, número relativamente pequeno considerando-se o período compreendido (o que já responde à crítica de que a ação implicaria o fim do controle concreto-difuso). Este universo deve ainda ser mais reduzido, pois 6 foram julgadas extintas sem julgamento do mérito por ilegitimidade ativa do proponente (ADCs 2, 6, 7, 10, 13 e 25), 1 por ter como objeto norma originária da Constituição (ADC 22), 1 por perda superveniente do objeto (ADC 8), 1 em que se pretendia que o STF adotasse "posicionamento jurídico" a respeito de determinada matéria (ADC 15), 1 em que ação proposta na verdade tinha "natureza de embargos de declaração" de uma decisão tomada em ADI (ADC 23), 1 que foi reautuada como ADI (ADC 28) e 1 que foi autuada de forma errada, tratando-se na verdade de MI (ADC 32). Portanto, a rigor, temos 20 ADCs, sendo que duas (ADCs 29 e 30) possuem o mesmo objeto.

Ainda que não se possa falar numa "jurisprudência" do STF neste caso, pois somente $10(\mathrm{dez})$ destas ações tiveram o mérito julgado (ADCs $1,3,4,5,9,12,16,19,29$ e 30), as decisões sobre questões preliminares ou sobre pedido de liminar nas 20 (vinte) ações efetivamente conhecidas já permitem uma análise da conformação da ADC pela Corte, ao menos no que tange a alguns aspectos que merecem destaque: (i) a caracteriza- 
ção da controvérsia judicial relevante, (ii) a causa petendi aberta e (iii) a concessão de medida cautelar.

Para a caracterização da controvérsia judicial relevante, o STF deixou de lado a exigência de decisões pela constitucionalidade da lei, bastando agora apenas a existência de decisões judiciais reconhecendo a inconstitucionalidade do ato normativo. Essa posição do STF foi tomada na ADC 8 (ação posteriormente considerada prejudicada por perda superveniente do objeto), a partir de uma interessante análise preliminar feita pelo relator, Ministro Celso de Mello, a respeito das 11 decisões pela constitucionalidade da lei trazidas aos autos pelo proponente da ação (no caso, o Presidente da República). O relator havia observado que, destas, somente três decisões - indeferitórias de medida liminar "de maneira mais específica, porém em caráter de cognição superficial, abordaram a quaestio iuris em causa"; nas demais, a questão constitucional não havia sido enfrentada. Não havia, portanto, um conjunto de decisões que, nas palavras do Min Moreira Alves no julgamento da ADC 1-QO, permitiria ao tribunal "o conhecimento das alegações em favor da constitucionalidade e contra ela, e do modo como estão sendo decididas num ou noutro sentido".

Atendendo à determinação do relator, para que se pronunciasse sobre este ponto, o Requerente, destacou que se deveria "fazer uma distinção acerca da exigência prévia do atendimento do pressuposto consistente na prova da controvérsia judicial, de 'proporções relevantes' (Ministro Pertence) em cotejo à sua demonstração 'em termos numericamente relevantes', conforme constou do despacho de V.Exa. [o relator]”. O argumento desenvolvido pelo Requerente - valendo lembrar que à época o Advogado-Geral da União era o hoje Ministro Gilmar Ferreira Mendes, talvez o autor desta manifestação - era de que, "em ambas as expressões, o valor jurídico a ser preservado é a mesma segurança jurídica, a ser observada em alcance e exigência relevante, para merecer a atuação jurisdicional da Suprema Corte" e que o quantitativo a que havia se referido o Ministro relator 
[...] se aplicaria, também, à observação de que uma medida judicial (tal uma ação civil pública, por exemplo) poderia, singularmente, veicular pedido de tutela jurisdicional em questão de interesse de milhares de cidadãos, aos quais seria devida a garantia da estabilidade das relações jurídicas, justamente o objeto da tutela da Declaratória, no caso concreto. [...]

As decisões judiciais que se manifestem pela inconstitucionalidade dos referidos dispositivos - sobre os quais milita a presunção de constitucionalidade -, trouxeram enorme insegurança à economia e às finanças públicas, pelo risco de não vir a ocorrer o ingresso dos recursos necessários à recomposição do caixa do sistema previdenciário oficial.

$\mathrm{O}$ argumentou convenceu o relator:

A existência de inúmeras decisões que afetam a presunção relativa de constitucionalidade - presunção esta que milita em favor de todos os atos legislativos - e o grau de indeterminação subjetiva daqueles que são favorecidos (ou eventualmente prejudicados) por deliberações judiciais proferidas em sede de processos coletivos geram, em consequência, situação de evidente insegurança jurídica quanto à validade desses diplomas normativos, justificando, sem qualquer dúvida, a utilização da ação declaratória de constitucionalidade, notadamente porque o julgamento do processo de controle normativo abstrato permitirá que se afaste, definitivamente, o cenário de perplexidade social e de grave comprometimento do sistema de direito positivo vigente do País.

A partir desta compreensão acerca da controvérsia judicial relevante, não se deve exigir decisões judiciais pela constitucionalidade da lei, sendo suficiente que haja decisões judicias que, reconhecendo a inconstitucionalidade da lei, gerem um "cenário de perplexidade social", "insegurança jurídica", enfim, um "grave comprometimento do sistema de direito positivo vigente no País”. O foco estaria então na consequência, e não na causa - ou mais na primeira do que na segunda. 
Se considerarmos que a orientação inicial do STF poderia ser sintetizada na ideia de que a controvérsia judicial permitiria ao tribunal "o conhecimento das alegações em favor da constitucionalidade e contra ela, e do modo como estão sendo decididas num ou noutro sentido" (Ministro Moreira Alves - ADC 1-QO), ao abandoná-la, o STF acertou e errou ao mesmo tempo. Acertou ao excluir a exigência de decisões judiciais pela constitucionalidade da lei. Além dos motivos já apontados para tanto, seria possível acrescentar mais um, de caráter pragmático: se é correto afirmar que os juízes fundamentam a não aplicação de uma lei por inconstitucionalidade, não se pode dizer ou esperar o mesmo quando aplicam uma lei cuja constitucionalidade se presume, tornando prescindíveis decisões nesse sentido ${ }^{7}$.

O STF acertou portanto em relação ao significado da controvérsia judicial exigida, mas errou na avaliação do importante papel que esta controvérsia desempenha na $\mathrm{ADC}$, e isso está mais relacionado à causa (as decisões judicias que geram a controvérsia) do que à consequência (a insegurança jurídica). A orientação inicial estava equivocada ao exigir decisões em ambos os sentidos acerca da constitucionalidade da lei, mas estava correta ao compreender que a exigência de demonstração da controvérsia judicial permitiria ao tribunal "o conhecimento das alegações" e "o modo como estão sendo decididas" pelas instâncias inferiores. É dizer: de alguma forma, vinculavam o STF às manifestações do Poder Judiciário, ainda que a Corte estivesse livre para decidir de outra forma. Conhecendo as interpretações dadas à lei e à Constituição, o STF daria a palavra final sobre a questão, mas pressupondo que houve uma palavra inicial, e que ela serviu para algo (causa) além de simplesmente gerar insegurança jurídica (consequência). A nova orientação parece mais inclinada a pôr um fim à controvérsia, pouco importando as interpretações que a geraram. Se correta essa análise, então a exigência de demonstração de controvérsia judicial relevante passa a ser apenas um requisito formal a autorizar a propositura da ADC, onde o STF dará a palavra final e tam-

Diante da orientação anterior do STF (ADC 1-QO), é compreensível que o Min. Celso de Mello tenha hesitado em prosseguir com o julgamento da ADC 8 ao se deparar com uma série de decisões judiciais pela constitucionalidade que em nada contribuíam para conhecimento de alegações em favor da lei. 
bém, de certo modo, a inicial acerca da constitucionalidade da lei, já que não teria o dever de conhecer dos - tampouco considerar os - argumentos construídos até então.

Não é tarefa fácil, contudo, afirmar o que a ADC tem sido no que tange ao requisito da controvérsia judicial relevante. Na ADC 17 (ainda não julgada), por exemplo, que tem por objeto dispositivos da Lei de Diretrizes e Bases da Educação, o relator, Ministro Ricardo Lewandowski, no mesmo despacho em que indeferiu o pedido de medida liminar, e valendo-se do que dispõe o artigo $20 \S \S 2^{\circ}$ e $3^{\circ}$, da Lei n. 9.868/1999, houve por bem solicitar

[...] informações ao Superior Tribunal de Justiça, bem como aos Tribunais de Justiça dos Estados de Mato Grosso do Sul, do Paraná, de São Paulo, do Amazonas e da Bahia, acerca da aplicação do dispositivo questionado nesta ação declaratória de constitucionalidade no âmbito de sua jurisdição.

O recurso a este dispositivo da Lei n. 9.868/99 (que também ocorreu nas ADCs 16, 24 e 26, embora voltada a apenas um tribunal) pode sinalizar para uma compreensão mais dialógica da controvérsia judicial relevante e do papel que ela deveria exercer na ADC.

Esse ponto está relacionado ao segundo aspecto que merece destaque: a causa petendi aberta da ADC. A ideia de que a Ação Direta de Inconstitucionalidade (ADI) possui causa de pedir aberta guarda algum sentido, ainda que seja curioso que o STF exija que o proponente da ação fundamente de forma consistente seu pedido, quando a Corte pode julgar a ação procedente por fundamento diverso. Todavia, em relação à ADC a causa petendi aberta perde quase ${ }^{8}$ completamente o sentido. $\mathrm{O}$ propósito da ADC, como visto no tópico anterior, é pôr fim a uma controvérsia judicial acerca da constitucionalidade de lei federal (ou parte dela), e as decisões judiciais pela inconstitucionalidade que geram a controvérsia não invalidam a lei perante toda a Constituição, mas diante de um ou al-

8 Com a ressalva apenas para a hipótese de se declarar a inconstitucionalidade da lei, julgando improcedente a ação, por fundamento diverso daquele que gerou a controvérsia judicial. 
guns dispositivos constitucionais específicos, a depender do caso. Cabe ao STF, se julgar procedente a ação, reafirmar a constitucionalidade da lei quanto ao ponto em discussão, e não simplesmente aproveitar a oportunidade para afirmar a constitucionalidade do ato normativo em face dos demais dispositivos que sequer foram objeto de interpretação pelas instancias ordinárias. Mais uma vez, aceitar que o STF possa ultrapassar os limites do que foi decidido pelas instâncias ordinárias, pondo um curioso fim a controvérsias que não existiram, implica atribuir à exigência de demonstração de controvérsia judicial relevante um caráter de requisito meramente formal (o que contraria a própria doutrina a respeito da ação, que tanto valoriza este requisito para assegurar a legitimidade da ADC).

O terceiro aspecto a ser destacado é preocupante por outras razões. A concessão de medida cautelar em ADC foi positivada na Lei n. 9.868/99 nos seguintes termos:

Art. 21 O Supremo Tribunal Federal, por decisão da maioria absoluta de seus membros, poderá deferir pedido de medida cautelar na ação declaratória de constitucionalidade, consistente na determinação de que os juízes e os Tribunais suspendam o julgamento dos processos que envolvam a aplicação da lei ou do ato normativo objeto da ação até seu julgamento definitivo.

Parágrafo único. Concedida a medida cautelar, o Supremo Tribunal Federal fará publicar em seção especial do Diário Oficial da União a parte dispositiva da decisão, no prazo de dez dias, devendo o Tribunal proceder ao julgamento da ação no prazo de cento e oitenta dias, sob pena de perda de sua eficacia.

A lei que regula o processo e julgamento da ADC estabeleceu, portanto, o efeito da concessão de medida cautelar (suspensão do julgamento dos processos que envolvam a aplicação da lei objeto da ação), o prazo de sua vigência (180 dias) e a consequência para o não julgamento da ação no prazo estabelecido, a saber, a perda de eficácia da cautelar concedida. Ou seja, o legislador assumiu que o STF poderia não conseguir julgar a ação dentro do prazo e, diante do risco que isso implicaria (suspensão de 
processos subjetivos), estabeleceu uma sanção clara e específica: a cautelar perderia sua eficácia. O tribunal, todavia, não tem aplicado a lei, da qual, a propósito, é o único destinatário.

Assim, em 2006, ao conceder a cautelar na ADC 12, o tribunal determinou a suspensão "até o exame de mérito desta ação" do julgamento dos processos que tinham por objeto questionar a constitucionalidade da Resolução n. 7, de 18 de outubro de 2005, do CNJ. Como observaram Dimoulis e Lunardi (2011, p. 156)

[...] foi dada uma interpretação de validade da liminar diferente da prevista no dispositivo legal, sendo que, neste caso, a liminar vigorou até a decisão definitiva, tomada em 2008. Essa interpretação extensiva dos efeitos da cautelar foi confirmada na ADC 11. A cautelar foi concedida em 2007. Em decisão de 2009, o STF prorrogou seus efeitos até a decisão final.

Os autos encontram-se conclusos ao relator desde março de 2013. $\mathrm{Na}$ ADC 18, o STF prorrogou a cautelar em fevereiro de 2009, depois em setembro do mesmo ano e em março de 2010, deixando registrado que seria prorrogado "pela última vez, por mais 180 (cento e oitenta) dias", o que de fato foi cumprido".

\section{O Que a ADC Deveria Ser}

A despeito do que o título deste tópico poderia sugerir, não pretendo aqui expor o que se esperava da ADC quando da criação desta nova ação de controle abstrato pelo Congresso Nacional. Sobre este ponto Mendes (2012, p. 457-465) faz um relato minucioso e satisfatório. "Deveria ser" tem aqui um caráter mais crítico-propositivo, diante de alguns problemas relativos a esta ação, ou ao modo como tem sido interpretada, e que poderiam comprometer a sua legitimidade. Os pontos problemáticos e que de al-

\footnotetext{
9 É o que se verifica no despacho de 25 de fevereiro de 2013: "Oficie-se aos magistrados que solicitaram informações a fls. 1.802, 2.031 e 2.054, noticiando já haver cessado, a partir de 21/09/2010, a eficácia do provimento cautelar do Supremo Tribunal Federal que suspendera a tramitação de processos cujo objeto coincidisse com aquele versado nesta causa".
} 
guma forma merecem revisão pelo STF são justamente aqueles destacados no tópico anterior: (i) a caracterização da controvérsia judicial relevante, (ii) a causa petendi aberta e (iii) a concessão de medida cautelar.

O STF deveria ser muito rigoroso ao admitir uma ADC por conta dos efeitos gerados pela procedência da ação, a saber: o fim de uma discussão sobre a constitucionalidade de determinada lei, ou algum(ns) de seus dispositivos. É importante enfatizar que o objetivo desta ação é pôr fim a uma controvérsia judicial relevante, confirmando a constitucionalidade da lei. Para que se ponha fim a algo é necessário que haja um começo, e a atuação do STF só será legítima na medida em que respeite esta premissa. É por essa razão, aliás, que não se pode reconhecer a ambivalência da ADI (LEITE 2008; RAMOS 2011), pois a sua improcedência não equivale à procedência de uma $\mathrm{ADC}$, já que não põe fỉm a uma controvérsia judicial, que pode sequer ter existido. ${ }^{10}$

Assim, considerando-se o propósito maior da ADC, o STF só deve admitir a ação quando houver material inicial a partir do qual a Corte dará a palavra final. Isso significa que não apenas deve haver controvérsia judicial relevante sobre a constitucionalidade de lei ou algum(ns) de seus dispositivos, mas que a controvérsia deve se dar a respeito do mesmo fundamento constitucional. Afinal, a rigor, a divergência entre juízes e tribunais não se dá em relação à lei, mas à Constituição. Tomemos como

${ }_{10}$ A despeito do que tem sido afirmado pela doutrina e pela jurisprudência, ADI e ADC não são ações iguais com sinal trocado, mas ações semelhantes. Há diferenças significativas entre as duas: objeto da ação; exigência de controvérsia judicial relevante (e sua comprovação nos autos); e manifestação do AGU. A ausência de defesa de constitucionalidade da lei pelo $\mathrm{AGU}$ não impede que se reconheça na improcedência da ADC uma declaração de inconstitucionalidade com efeito vinculante e eficácia contra todos (LEITE 2013). Seria um rigor excessivo exigir que o AGU defendesse a constitucionalidade da lei numa ação proposta justamente para confirmar a constitucionalidade do ato normativo - sobretudo depois que o próprio STF, numa de suas atuações que desafiam o conceito de interpretação (ADI 3916), entendeu que, no processo de ADI, o AGU pode se manifestar pela inconstitucionalidade da lei. Ou seja, a Corte converteu o dever de defesa pela constitucionalidade (art. 103, $\S 3^{\circ}, \mathrm{CRFB}$ ) em direito de manifestação sobre a constitucionalidade (LEITE, 2010), tornando o AGU uma espécie de parecerista, ainda que nenhum dispositivo constitucional autorize esta leitura. Já a ADI, mesmo quando seu objeto for lei federal, não poderá ser ambivalente, pela ausência da controvérsia judicial relevante, imprescindível para a propositura da ADC. 
exemplo hipotético a lei de arbitragem (9.307/96). Se juízes e tribunais divergissem a respeito da sua constitucionalidade, por suposta violação ao princípio do acesso do Poder Judiciário (art. $5^{\circ}, \mathrm{XXXV}, \mathrm{CRFB}$ ), a divergência seria a respeito do alcance do dispositivo constitucional e não do significado da lei, bem claro em seus termos. Portanto, se o STF dará a palavra final neste caso, dará a palavra final sobre a interpretação do dispositivo constitucional em questão, o que pressupõe uma controvérsia a este respeito. Se a lei tivesse sido considerada inconstitucional por juízes ou tribunais em três ou quatro ações individuais sob este fundamento, e inconstitucional em outras três ou quatro ações sob outro fundamento constitucional, não haveria rigorosamente uma controvérsia judicial relevante que permitisse o ajuizamento de uma ADC. O STF deveria valorizar o fundamento da controvérsia, pois é sobre este ponto que a Corte dará a palavra final, e não sobre a lei em si.

Quanto à causa petendi aberta, trata-se de uma ideia que deve ser abandonada (ao menos parcialmente). Admitir a causa petendi aberta significaria reconhecer que numa ADC julgada procedente o STF confirmaria a constitucionalidade da lei objeto da ação não apenas face ao dispositivo constitucional que deu ensejo à controvérsia judicial, mas também face a todos os demais. A ideia em si é absurda por uma série de razões. É humanamente impossível que se avalie a constitucionalidade da lei, ex officio, a partir de todos os dispositivos constitucionais, e a partir de todas as interpretações possíveis a respeito destes dispositivos (o que engloba interpretações que sequer chegaram ao conhecimento do STF e as que sequer foram suscitadas pela Corte). Além disso, se ao STF fosse autorizado confirmar a constitucionalidade da lei diante de dispositivos constitucionais que não foram considerados pelas instâncias inferiores, no controle concreto-difuso, qual seria a razão de se exigir a controvérsia judicial, cuja importância foi sempre destacada tanto pelo STF como por toda a doutrina? A controvérsia judicial se justifica somente na medida em que permita ao STF dar a palavra final a respeito da questão ali suscitada. Portanto, a confirmação da constitucionalidade da lei deve ocorrer nos limites da dúvida suscitada, que gerou a controvérsia, e considerando-se as interpretações realizadas pelas instâncias inferiores, para que a interpretação do STF não seja apenas a última, mas também a melhor. 
Considere a seguinte situação. O STF julga procedente uma ADC que tinha por objeto uma lei federal $\mathrm{X}$, cuja constitucionalidade fora alvo de controvérsia judicial, já que muitos juízes a consideravam inconstitucional sob o argumento de que a lei violaria o princípio da isonomia. Meses depois, um juiz, ao julgar um caso concreto, deixa de aplicar a referida lei sob um sólido fundamento de que a competência para tratar da matéria seria dos Estados e não da União. Contra esta decisão, seria cabível Reclamação ao STF, já que a declaração de constitucionalidade em ADC tem efeito vinculante. Se a Corte concordasse com a interpretação constitucional feita pelo magistrado, teria que julgar improcedente a Reclamação. Mas sob que fundamento o tribunal o faria? $\mathrm{O}$ de que não havia considerado este aspecto - o que colocaria em questão a ideia da causa petendi aberta? Ou o de que "mudou" seu entendimento - o que seria muito curioso e pouco honesto?

A causa petendi aberta é admitida, sem maior polêmica, na ADI porque neste caso o que ocorre é a declaração de inconstitucionalidade, questão de interesse público, o que permite ao STF identificar, ex officio, outro dispositivo constitucional que estaria sendo violado, que não aquele invocado pelo proponente da ação. É por essa razão que se pode admitir a causa petendi aberta em ADC quando o tribunal entender que a lei, embora constitucional diante do dispositivo objeto da controvérsia judicial, é inconstitucional por afrontar outro dispositivo que não havia sido suscitado pelo proponente. É dizer: a causa petendi aberta só se aplica em caso de improcedência no mérito da ADC.

Por fim, o STF não pode prorrogar o prazo de 180 dias da medida cautelar, como fez nos processos citados no tópico anterior. Aliás, o que espanta nessas decisões é a facilidade que o tribunal encontrou para deixar de observar a lei, quando se sabe que as decisões contra legem impõem um considerável ônus argumentativo ao intérprete. "O perigo da pedra que desce a montanha", no entanto, já poderia ser visto num texto de autoria de Gilmar Mendes (MARTINS; MENDES, 2001), antes de se tornar Ministro do STF, ao tratar do tema (posição que sustenta ainda hoje: MENDES 2012, p. 504-505): 
Tenho pra mim que o prazo poderá ser ultrapassado, renovando a Suprema Corte a eficácia do decidido, se não puder julgar em 180 dias o processo de forma definitiva. É que o conteúdo da expressão 'sob pena de perda de sua eficácia' será decidido pela própria $\mathrm{Su}-$ prema Corte, que é a guardiã da Constituição e que poderá entender que o julgamento em 180 dias é impossível em face do acúmulo de trabalho, dando à norma a interpretação que se tem dado à eficácia de 120 dias atribuída pela lei às liminares em mandado de segurança, cuja prorrogação além do prazo legal tem sido uma constante, a critério do próprio magistrado, até porque a liminar é concedida em vista de requisitos próprios, e seus efeitos devem ser mantidos enquanto presentes tais requisitos.

A sinalização parece-me, pois, mais um princípio programático ordinário do que regra que deverá ser seguida pela Suprema Corte, que não retirará eficácia às suas próprias decisões, por força de um prazo de impossível cumprimento. (MARTINS; MENDES, 2001, p. 283)

A posição defendida pelo Ministro não convence ${ }^{11}$. O dispositivo legal tem as características típicas de regra jurídica: há um predicado fático e a sua consequência. $\mathrm{O}$ que se poderia questionar é se caberia ao legislador limitar dessa forma a medida cautelar em ADC, que o STF havia conformado diretamente a partir do texto constitucional, que permanece silente a este respeito ${ }^{12}$. Para responder, devemos considerar que há razões fortes que justificam a regra - razões que podem não ser do agrado do Ministro, nem se conformar à ideia de Guardião da Constituição tal como ele a concebe e defende, mas nem por isso deixam de ser legítimas

\footnotetext{
11 Aparentemente Dimoulis e Lunardi (2011, p. 157) também não concordam com esta interpretação extensiva, pois concluem o tópico sobre a cautelar em ADC afirmando que "[...] a decisão da cautelar apresenta ainda efeitos vinculantes e erga omnes, devendo ser respeitado, como dissemos, o prazo de eficácia de 180 dias".

12 Zavascki (2012, p. 79), por exemplo, ao tratar do efeito da cautelar segundo o art. 21 da lei 9868/99, afirma categoricamente que "não cabe ao legislador ordinário estabelecer, numerus clausus, as configurações que ditas providências [que o Poder Judiciário entenda necessárias para afastar o periculum in mora] podem assumir, nem limitar o seu alcance de forma que iniba a consecução da finalidade a que se destinam", concluindo que o tribunal pode e eventualmente deve conceder efeitos outros que não aquele determinado pela lei (suspensão dos processos).
} 
e válidas. O efeito da concessão de cautelar é a suspensão de processos judiciais que visam à tutela de direitos subjetivos. Ocorre aqui uma ponderação feita pelo legislador, privilegiando a presunção de constitucionalidade da lei objeto da ADC, confirmada em sede cautelar, em prejuízo de outros bens e valores constitucionais, como a duração razoável do processo (art. 5, LXXVIII, CRFB) ou a inafastabilidade da jurisdição (art. $5, \mathrm{XXXV}, \mathrm{CRFB}$ ) em seu sentido mais abrangente. Não poderia o legislador entender que o resultado desta ponderação só se justifica dentro de um prazo razoável (no caso, 180 dias)? E que, ultrapassado este prazo, os efeitos da suspensão de processos judicias onde direitos subjetivos estão em discussão adquirem uma importância maior, sendo preferível assumir os riscos (muitos deles reversíveis) de que juízes e tribunais decidam os casos concretos reconhecendo a inconstitucionalidade da lei, quando o STF já sinalizou pela sua constitucionalidade (apresentando argumentos para tanto, supõe-se)? É aliás aqui que reside a inadequação da analogia feita pelo Ministro com a legislação - já revogada - que era aplicada às liminares em mandado de segurança, pois a ponderação feita pelo legislador neste caso - e talvez não por acaso tenha sido abandonada - poderia de fato ser prejudicial à tutela do direito subjetivo. $O$ fato de que na cautelar em ADC se está diante de um processo objetivo que suspende processos subjetivos faz uma diferença suficiente para comprometer a analogia.

Interessante observar que, na ADC 18, o STF chegou a ser provocado, por meio de embargos de declaração, a se manifestar sobre a legalidade da prorrogação da eficácia da cautelar, sob o argumento de que "[...] o princípio da inafastabilidade da jurisdição impediria a prorrogação, pelo Supremo Tribunal Federal, do prazo de 180 (cento e oitenta) dias previsto no art. 21 da Lei n. 9.868/1999". Os embargos contudo não foram conhecidos, por ilegitimidade recursal do embargante ("amicus curiae") e por serem extemporâneos.

\section{Conclusão}

O trabalho demonstrou que a ADC é uma ação mais complexa do que a ideia de uma simples "ADI com sinal trocado" poderia sugerir. Há 
uma distância entre o que se afirma na teoria e o que ocorre na prática, como no ponto relativo à controvérsia judicial relevante, tão enaltecido quando se trata de justificar a ADC, e tão ignorado quando doutrina e STF defendem a ambivalência da ADI. Ajudaria se a redação do artigo 24 fosse mais fiel à realidade e dispusesse que, julgada procedente a ADC, seria "confirmada" - e não "declarada" - a constitucionalidade da lei "federal". Deixaria claro de certo modo que não há espaço para ambivalência da ADI, pois a sua improcedência não põe fim a uma controvérsia judicial (comprovada nos autos da ação).

Há questões ainda ausentes no debate sobre esta ação, relativas à fundamentação das decisões judiciais, o que vale tanto para aquelas que geram a controvérsia como para a própria decisão do STF na ADC. Valorizar a fundamentação é essencial para a legitimidade da ADC, e por uma série de motivos.

Exigir que a controvérsia gire em torno de um mesmo fundamento limita o poder do STF - o que por si só já seria positivo em qualquer regime constitucional. Mas, além disso, garante que o STF irá efetivamente pôr fim a uma controvérsia, e não começar e terminar uma. Ainda: a Corte deverá encerrar uma controvérsia considerando todo o trabalho desenvolvido pelas instâncias inferiores, assegurando, assim, uma qualidade superior à sua decisão.

A ênfase nos pontos acima é suficiente para se abandonar a ideia de causa petendi aberta na ADC. Afinal, se já há um grave problema quando o STF praticamente dá início a um debate a respeito da interpretação de um dispositivo constitucional, o que dizer de quando este debate sequer ocorre e ainda assim deve-se considerar que a questão (qual?) foi decidida porque a causa petendi é aberta? Não há nada no texto constitucional ou fora dele que garanta, ou mesmo sugira, que o STF é o melhor intérprete da Constituição; é apenas o último a interpretá-la, o que implica uma considerável responsabilidade. E é também por conta desta responsabilidade que a Corte deve rever sua posição a respeito da prorrogação de prazo para suspensão de processos na cautelar da ADC. Se o que justifica a ADC, de acordo com a jurisprudência do STF, é a alegada insegurança jurídica que resulta do controle concreto-difuso, onde juízes e tribunais 
deixam de aplicar uma lei por considera-la inconstitucional, o que dizer da situação onde o STF deixa de aplicar um dispositivo legal (art. 21, parágrafo único da Lei n. 9.868/99) sem um fundamento adequado? O respeito à jurisprudência do STF deveria ser conquistado, e não imposto.

\section{Referências}

BARROSO, Luís Roberto. O Controle de Constitucionalidade no Direito Brasileiro. São Paulo: Saraiva, 2004.

DIMOULIS, Dimitri; LUNARDI, Soraya. Curso de Processo Constitucional. São Paulo: São Paulo, 2011.

HABERLE, Peter. Hermenêutica Constitucional - a sociedade aberta dos intérpretes da Constituição: contribuição para a interpretação pluralista e "procedimental" da Constituição. Tradução Gilmar Ferreira Mendes. Porto Alegre: Sergio Antonio Fabris Editor, 2007. LEITE, Fábio Carvalho. ADIN e ADC, e a ambivalência possível: uma proposta. Revista de Direito do Estado, Rio de Janeiro, v. 10, Renovar, 2008.

LEITE, Fábio Carvalho. ADIN e ADC, e a ambivalência possível: uma proposta (revista). In: ASENSI, F.; GIOTTI, D. (Org.). Tratado de direito constitucional. Rio de Janeiro: Campus-Elsevier, 2013. (prelo)

LEITE, Fábio Carvalho. O papel do Advogado-Geral da União no controle abstrato de constitucionalidade: curador da lei, advogado público ou parecerista? Revista Nomos, Ceará, Programa de Pós-Graduação em Direito da Universidade Federal do Ceará, 2011.

LEITE, Fábio Carvalho. A Cláusula de Reserva de Plenário Segundo os Tribunais de Justiça. In: Direitos Fundamentais \& Justiça/Pontifícia Universidade Católica do Rio Grande do Sul. Programa de PósGraduação, Mestrado e Doutorado, n. 15, abr.-jun. 2011. Porto Alegre: Editora, 2011. 
MARTINS, Ives Gandra da Silva; MENDES, Gilmar Ferreira. Controle Concentrado de Constitucionalidade: comentários à Lei n. 9.868/99. São Paulo: Saraiva, 2001.

MENDES, Gilmar Ferreira. Controle Abstrato de Constitucionalidade: ADI, ADC e ADO - comentários à Lei n. 9.868/99. São Paulo: Saraiva, 2012.

RAMOS, Elival da Silva. Controle de Constitucionalidade no Brasil: perspectivas de evolução. São Paulo: Saraiva, 2010. ZAVASCKI, Teori Albino. Eficácia das sentenças na jurisdição constitucional. 2. ed. São Paulo: Editora Revista dos Tribunais, 2011.

Fábio Carvalho Leite é Professor de Direito Constitucional dos cursos de graduação e pós-graduação da Pontifícia Universidade Católica do Rio de Janeiro (PUC-Rio). Mestre em Teoria do Estado e Direito Constitucional (PUCRio) e Doutor em Direito Público (UERJ). Coordenador do Núcleo de Estudos Constitucionais da PUC-Rio. Assessor Jurídico da Reitoria da PUC-Rio.

E-mail: fabiojur@puc-rio.br

Endereço profissional: Pontíficia Universidade Católica do Rio de Janeiro, Rua Marquês de São Vicente, 225, Gávea, RJ, Brasil. 
